\title{
Transmission of vibrations from the ground to the foundation from the movement of passenger trains
}

\author{
Filip Pachla \\ Cracow University of Technology, Cracow, Poland \\ E-mail:fpachla@pk.edu.pl
}

Received 10 September 2019; accepted 17 September 2019 DOI https://doi.org/10.21595/vp.2019.21023

Check for updates

Copyright $(2019$ Filip Pachla. This is an open access article distributed under the Creative Commons Attribution License, which permits unrestricted use, distribution, and reproduction in any medium, provided the original work is properly cited.

\begin{abstract}
The article presents the results of vibration measurements from passenger train journeys from the ground to the building foundation. The vibration acceleration courses from the Pendolino passenger train were used for the analysis. The measurements were carried out in a single-family brick building at the existing railway line. The measurement results can be used in the future to analyze buildings located at railway lines where passenger traffic takes place. The results of the analyzes can also be useful in assessing the impact of vibrations from the railway line on people staying in buildings.
\end{abstract}

Keywords: railway, vibrations, HST, soil-structure interaction.

\section{Introduction}

The problem of vibrations transmitted through the subsoil from railway lines is a current and important problem. In Poland, we observe an intense development of railway infrastructure. Vibration forecasts must be made when new railway lines are created or existing ones are upgraded. Numerical analyzes are often used for this purpose $[1,2]$. There is often a problem of choosing the right kinematic excitation. During measurements, you can measure the acceleration of vibrations on the ground in front of the building or on the building foundation. However, the differences in measured vibration values are significant. In the literature you can find the results regarding the propagation of vibrations in the ground [3-5] as well as their impact on the building [6]. The article presents the results of transmission of vibrations from the ground to the building. Such results may in the future be used to assess the effects of vibrations on the building [6] or on humans in the buildings [3].

\section{Field tests}

The research was carried out at one of the main railway lines in Poland. Railroad No. 4 connects Grodzisk Mazowiecki with Zawiercie. It was adapted to service passenger trains at speeds up to $200 \mathrm{~km} / \mathrm{h}$ and freight trains at speeds of $120 \mathrm{~km} / \mathrm{h}$. The tests were carried out for passenger trains. All recorded vibrations come from the Pendolino ED250 train. It is a seven-section, standard-gauge high-speed electric multiple unit (see Fig. 1). At the time of measurement, trains could travel at this section at a maximum speed of $160 \mathrm{~km} / \mathrm{h}$. The tests were carried out on a single-family building with a traditional structure (see Fig. 2). The building is located $33 \mathrm{~m}$ from the railway line. Accelerations of ground vibrations were measured using PCB 393B12 accelerometers in three orthogonal directions on the foundation and on the ground in front of the building. Fig. 3 shows an example of a measuring point on the foundation.

\section{Measurement results with analysis}

Fig. 4 shows the results of vibration measurements in the $x, y, z$ directions on the building foundation from passage No. 1. The values of vibration accelerations do not exceed $2 \mathrm{~cm} / \mathrm{s}^{2}$. Fig. 5, on the other hand, shows the results of acceleration of soil vibrations in front of the building also in three orthogonal directions from passage No. 1. 


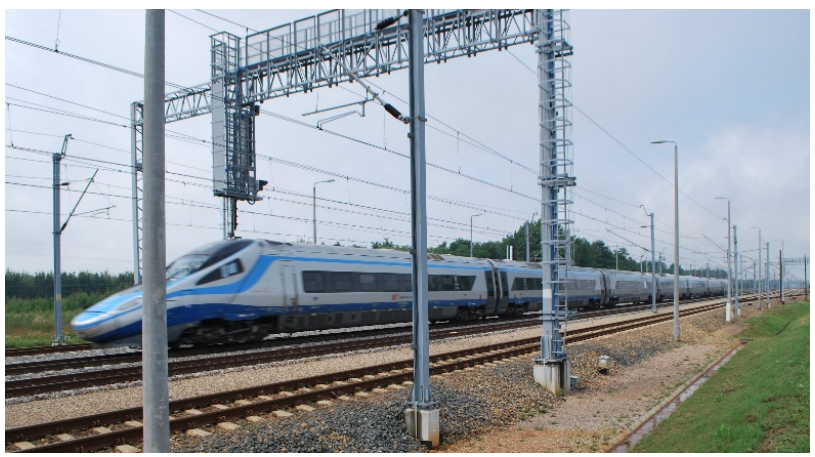

Fig. 1. The analyzed passenger train - code name Pendolino

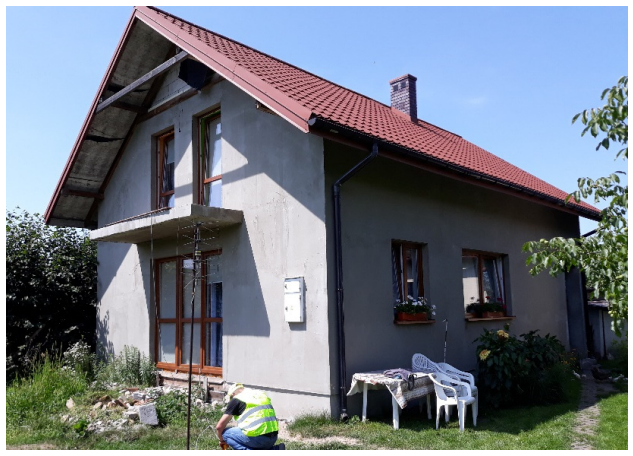

Fig. 2. The analyzed building

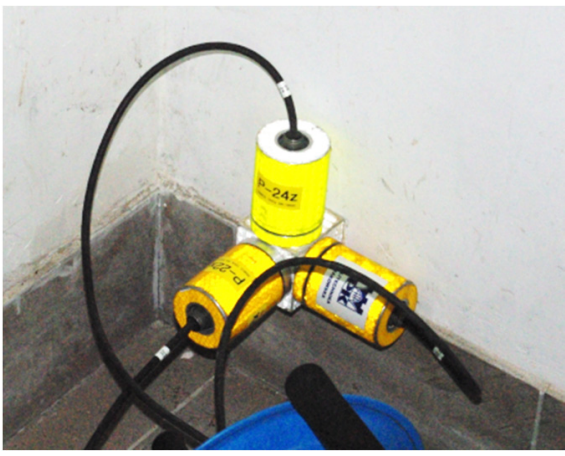

Fig. 3. Acceleration sensors mounted on the foundation of the building

From the graph it can be observed that the maximum values of accelerations of soil vibrations before a boring are close to $20 \mathrm{~cm} / \mathrm{s}^{2}$. Comparison of measurements from sensors on the foundation and ground is shown in Fig. 6 . Table 1 shows the results of the maximum values of vibration acceleration on the foundation (PFA) and ground (PGA).

Table 1. Vibration acceleration peak values

\begin{tabular}{|c|c|c|c|c|c|c|c|}
\hline No. & $\begin{array}{c}\text { Speed } \\
{[\mathrm{km} / \mathrm{h}]}\end{array}$ & $\begin{array}{c}\text { PFAx } \\
{\left[\mathrm{cm} / \mathrm{s}^{2}\right]}\end{array}$ & $\begin{array}{c}\text { PFAy } \\
{\left[\mathrm{cm} / \mathrm{s}^{2}\right]}\end{array}$ & $\begin{array}{c}\text { PFAz } \\
{\left[\mathrm{cm} / \mathrm{s}^{2}\right]}\end{array}$ & $\begin{array}{c}\text { PGAx } \\
{\left[\mathrm{cm} / \mathrm{s}^{2}\right]}\end{array}$ & $\begin{array}{c}\text { PGAy } \\
{\left[\mathrm{cm} / \mathrm{s}^{2}\right]}\end{array}$ & $\begin{array}{c}\text { PGAz } \\
{\left[\mathrm{cm} / \mathrm{s}^{2}\right]}\end{array}$ \\
\hline 1 & 153 & 1.12 & 1.15 & 1.55 & 25.29 & 17.16 & 9.92 \\
\hline 2 & 130 & 0.84 & 1.01 & 0.98 & 7.45 & 6.17 & 4.00 \\
\hline 3 & 153 & 0.86 & 1.09 & 1.62 & 14.95 & 11.72 & 7.82 \\
\hline 4 & 146 & 1.21 & 1.67 & 2.33 & 20.68 & 8.93 & 9.22 \\
\hline 5 & 161 & 0.91 & 1.05 & 1.67 & 13.67 & 8.62 & 6.74 \\
\hline 6 & 154 & 1.11 & 1.42 & 1.84 & 16.04 & 11.33 & 6.60 \\
\hline 7 & 150 & 1.12 & 1.66 & 1.42 & 14.15 & 8.76 & 6.84 \\
\hline 8 & 136 & 1.05 & 1.49 & 1.78 & 13.65 & 7.00 & 4.12 \\
\hline 9 & 151 & 0.94 & 0.81 & 1.39 & 13.80 & 8.77 & 6.34 \\
\hline 10 & 150 & 0.93 & 1.06 & 1.50 & 13.31 & 9.40 & 5.82 \\
\hline 11 & 146 & 0.91 & 0.87 & 1.08 & 13.38 & 8.92 & 6.67 \\
\hline 12 & 133 & 0.78 & 0.80 & 0.98 & 12.97 & 11.81 & 7.55 \\
\hline 13 & 152 & 0.88 & 1.15 & 1.44 & 13.62 & 9.17 & 7.09 \\
\hline 14 & 124 & 1.17 & 1.87 & 1.60 & 17.10 & 7.31 & 5.67 \\
\hline
\end{tabular}

Analyzing the data in Table 1, it can be seen that the ground vibration accelerations are 2.3 to 22.6 times higher than the vibrations recorded in the same direction on the foundation. The greatest reduction of bastards is recorded when vibration passes from the ground to the foundation in the 
$x$ direction. The $x$ direction is perpendicular to the track axis. The smallest reductions in the vertical direction $z$.

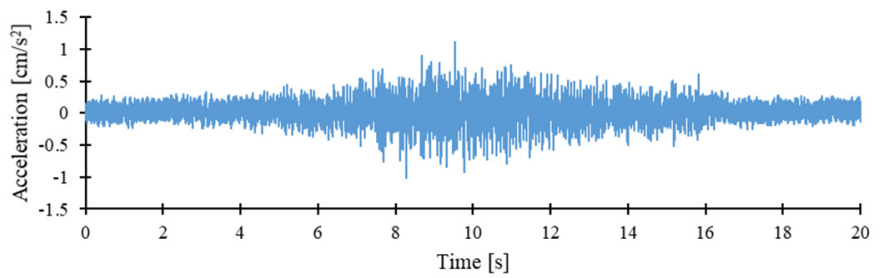

a)

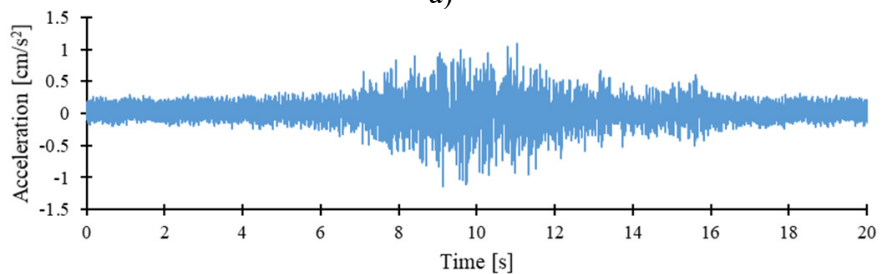

b)

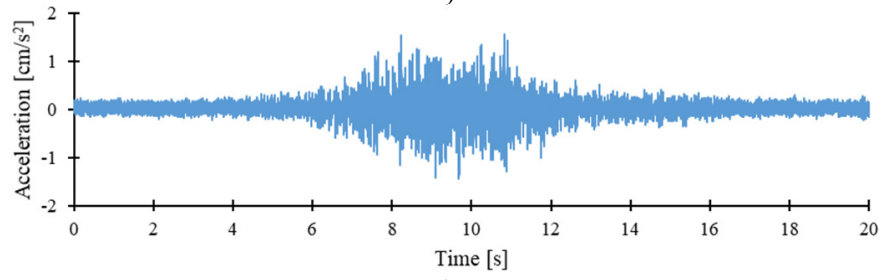

c)

Fig. 4. Ground vibration acceleration - No. 1

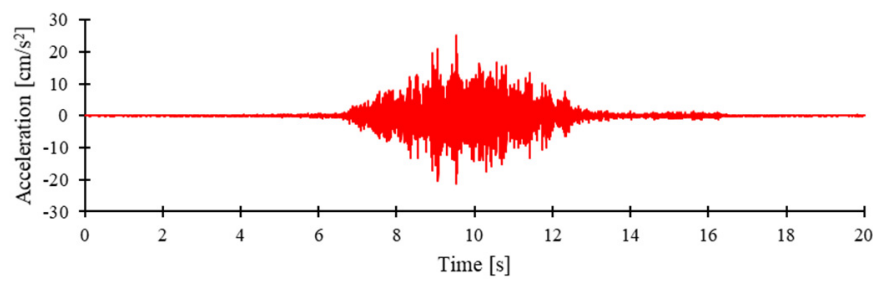

a)

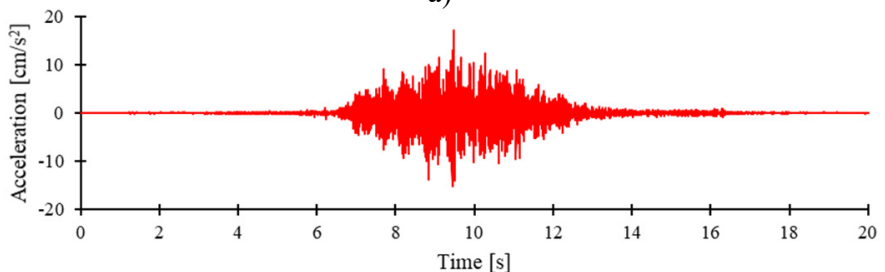

b)

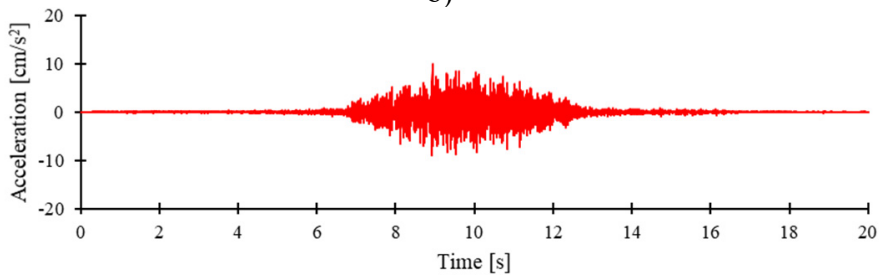

c)

Fig. 5. Acceleration of foundation vibrations - No. 1 


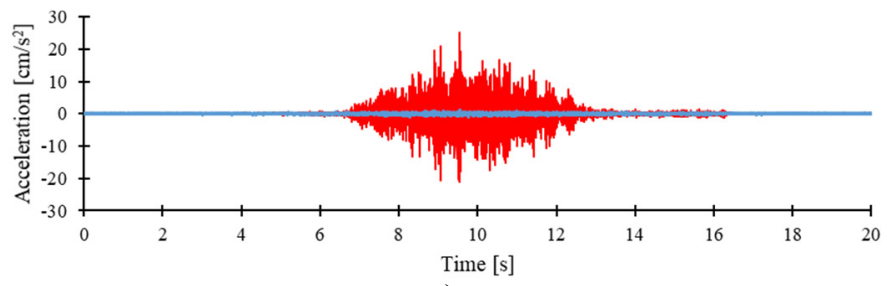

a)

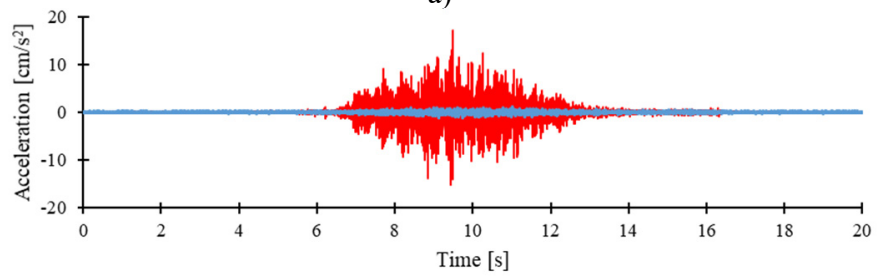

b)

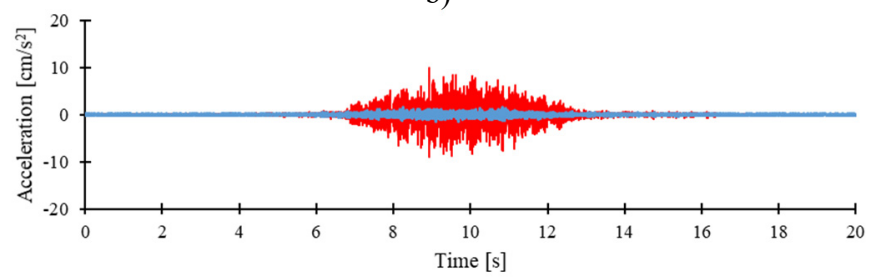

c)

Fig. 6. Comparison of ground and foundation vibration accelerations

\section{Conclusions}

The research results show a rather characteristic mechanism of vibration propagation from soil to foundation. One can observe a reduction of the peak vibration accelerations by several times. The largest reduction was observed on the horizontal component perpendicular to the axis of the railway track. Slightly smaller in the direction parallel to the track axis, and the smallest in the vertical direction. The presented test results can be useful when analyzing vibrations on buildings and humans in the buildings.

\section{References}

[1] Connolly D. P., Kouroussis G., Woodward P. K., Alves Costa P., Verlinden O., Forde M. C. Field testing and analysis of high speed rail vibrations. Soil Dynamics and Earthquake Engineering, Vol. 67, 2014, p. 102-118.

[2] Pachla F. The impact of the passenger train speed on the comfort of humans in a building close to the railway. Vibroengineering Procedia, Vol. 19, Issue 2018, 2018, p. 147-152.

[3] Kowalska Koczwara A., Pachla F., Stecz P., Stypuła K., Tatara T., Lejk J., Sokołowski M. Vibration-based damage identification and condition monitoring of metro trains: Warsaw Metro case study. Shock and Vibration, Vol. 2018, 2018, p. 8475684.

[4] Zhai W., Wei K., Song X., Shao M. Experimental investigation into ground vibrations induced by very high speed trains on a non-ballasted track. Soil Dynamics and Earthquake Engineering, Vol. 72, 2015, p. 24-36.

[5] Stypula K., Tatara T. Vibrations of free-field and building caused by passages of the Pendolino train. Technical Transactions, Vol. 114, Issue 1, 2017, p. 85-100.

[6] Pachla F., Radecki Pawlik B., Stypula K., Tatara T. Vibration induced by railway traffic-zones of influence on buildings and humans. Vibroengineering Procedia, Vol. 13, Issue 2017, 2017, p. 188-192. 